Sains Malaysiana 48(8)(2019): 1635-1642

http://dx.doi.org/10.17576/jsm-2019-4808-09

\title{
Chemical Analysis on the Honey of Heterotrigona itama and Tetrigona binghami from Sarawak, Malaysia
}

(Analisis Kimia pada Madu Heterotrigona itama dan Tetrigona binghami dari Sarawak, Malaysia)

\author{
Pearly Wong, Hit Siew Ling*, Koh Chen Chung, Thomas Moh Shan Yau \& Suzy Rini Anak Gindi
}

\begin{abstract}
This study aims to compare the chemical composition of honey samples produced by Heterotrigona itama and Tetrigona binghami which originated from Sarawak, Malaysia. One hundred and six (106) honey samples were collected from local bee farms and analysed in terms of their chemical profiles. The chemical analysis conducted includes physicochemical composition such as moisture, total phenolic content, sugar, 5-hydroxymethylfurfural (5-HMF), pH and organic acids and proximate analysis which included ash, protein, carbohydrates and energy. Independent T-test was used as a statistical tool to investigate the significant difference between the composition of both honey samples. The results showed that honey samples of Heterotrigona itama and Tetrigona binghami possessed significant difference $(\mathrm{p}<0.05)$ in moisture, total phenolic content, fructose, glucose, pH, protein, gluconic acid, acetic acid, ash, carbohydrates and energy. The honey samples of Heterotrigona itama exhibited significantly higher fructose and glucose at the average of $22.00 \pm 3.48$ $\mathrm{g} / 100 \mathrm{~g}$ and $23.45 \pm 3.23 \mathrm{~g} / 100 \mathrm{~g}$, respectively. Besides, the honey samples also possessed higher pH value, gluconic acid, ash, carbohydrates and energy. Meanwhile, Tetrigona binghami honey samples possessed significantly $(\mathrm{p}<0.05)$ higher moisture content, total phenolic content, protein and acetic acid compared to the Heterotrigona itama's honey samples. To conclude, the geographical and floral origins of honey are the two important quality parameters which fundamentally affect the physical-chemical properties as well as biological activities of honey samples.
\end{abstract}

Keywords: Heterotrigona itama; Sarawak; species; stingless bee honey; Tetrigona binghami

ABSTRAK

Kajian ini bertujuan untuk membandingkan komposisi kimia sampel madu yang dihasilkan oleh Heterotrigona itama dan Tetrigona binghami yang berasal dari Sarawak, Malaysia. Seratus enam (106) sampel madu diambil dari ladang lebah tempatan dan dianalisis daripada segi profil kimia mereka. Analisis kimia dijalankan termasuk komposisi fizikokimia seperti kelembapan, jumlah kandungan fenolik, gula, 5-hidroksimetilfurfural (5-HMF), pH dan asid organik dan analisis proksimat termasuk abu, protein, karbohidrat dan tenaga. Ujian-T bebas digunakan sebagai alat statistik untuk mengkaji perbezaan yang ketara antara komposisi kedua-dua sampel madu. Hasil menunjukkan bahawa sampel madu Heterotrigona itama dan Tetrigona binghami mempunyai perbezaan yang signifikan ( $<0.05)$ daripada segi kelembapan, jumlah kandungan fenolik, fruktosa, glukosa, pH, protein, asid glukonik, asid asetik, abu, karbohidrat dan tenaga. Sampel madu Heterotrigona itama menunjukkan fruktosa dan glukosa yang lebih tinggi masing-masing pada purata $22.00 \pm 3.48 \mathrm{~g} / 100 \mathrm{~g}$ dan $23.45 \pm 3.23 \mathrm{~g} / 100 \mathrm{~g}$. Selain itu, sampel madu kajian juga memiliki nilai pH lebih ting gi, asid glukonik, abu, karbohidrat dan tenaga. Sementara itu, sampel madu Tetrigona binghami mempunyai kandungan lembapan yang tinggi $(\mathrm{p}<0.05)$ secara signifikan, jumlah kandungan fenolik, protein dan asid asetik berbanding sampel madu Heterotrigona itama. Sebagai kesimpulan, asal-usul geografi dan bunga madu adalah dua parameter penting yang pada dasarnya mempengaruhi sifat fizikal-kimia serta aktiviti biologi sampel madu.

Kata kunci: Heterotrigona itama; madu lebah tiada sengat; Sarawak; spesies; Tetrigona binghami

\section{INTRODUCTION}

Stingless bees (Meliponini) belong to the order of Hymenoptera in the family of Apidae. They consist of five generas, the most common being Trigona and Melipona. The Meliponinae are the only group of bees which have been imprinted in the fossil record spanning most of the Cenozoic (Rasmussen \& Cameron 2009). The cultural importance of the species known as Xunan-Kab (Melipona beecheii), was recorded by the Maya in their codices (Cortopassi-Laurino et al. 2006). As highly eusocial insects, stingless bees exhibit extreme task specialisation especially in collecting nectars. Besides, they are also recognised for their role as natural pollinator and provider of the ecosystem service. Stingless bees do not sting but they may have large colonies for their nest protection.

To date, over eight hundred (800) species in 61 named genera of the stingless bee reside in most tropical and subtropics rainforest around the globe, mainly in South America, Africa, Australia and Asia (Cortopassi-Laurino et al. 2006; Michener 2013). In Malaysia, a total of 
twenty-nine (29) stingless bee species was documented in Peninsular Malaysia and out of this, 17 species were known to inhabit the virgin forest. The most common meliponiculture species in Malaysia are Heterotrigona itama (Figure 1) due to the high demand and abundance. Heterotrigona itama is known as a pollinating agent for most of the crops in Malaysia. Meliponiculture is a term used for stingless bee keeping. The domestication of all Malaysian stingless bee species could not be achieved as some forest stingless bee species such as Tetrigona binghami (Figure 2) is resin dependent (Jaapar et al. 2016; Leonhardt et al. 2011). Removal of these species from the rainforest will collapse their habitat as there are no resources for their food and hives.

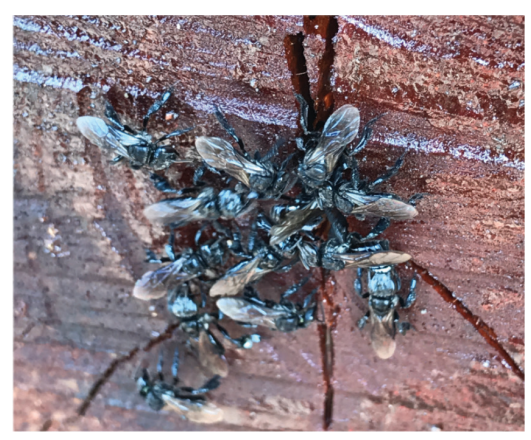

FIGURE 1. Heterotrigona itama bees

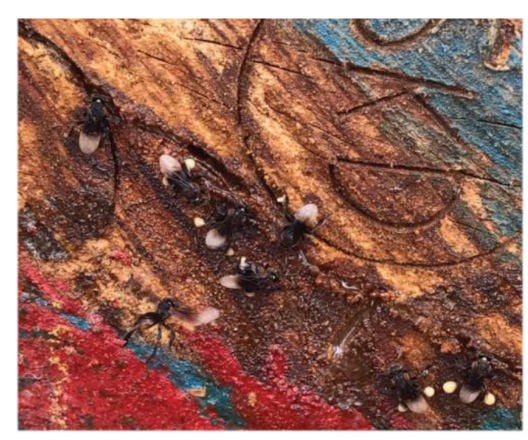

FIGURE 2. Tetrigona binghami bees

The honey of stingless bees is a sugary liquid with a sour taste and aroma. It can be grouped into a few categories according to its physical and chemical constituents, which are fundamentally related to the physiology of the production of the raw material, ethnological and botanical sources, geographical origin, bee species and conditions of the ecosystem of the habitat (Alvarez-Suarez et al. 2010; Badolato et al. 2017; Escuredo et al. 2014; Kek et al. 2017; Sousa et al. 2016). Several researchers reported that the variability of the chemical compositions and characteristics of honey are dependent on the bee species and botanical origin (Boussaid et al. 2018; Gül \& Pehlivan 2018; Kumar et al. 2018; Tuksitha et al. 2018). There are significant differences in terms of the composition of the stingless bees honey produced by different bee species and geographical origins such as Brazil (Biluca et al. 2016; Da Silva et al.
2013; Sousa et al. 2016), Thailand (Chuttong et al. 2016) and Malaysia (Kek et al. 2014; Moniruzzaman et al. 2014; Tuksitha et al. 2018). As an example, the moisture content of the stingless bees honeys, Homotrigona fimbriata and Lepidotrigona terminata from Thailand are $41 \mathrm{~g} / 100 \mathrm{~g}$ and $30 \mathrm{~g} / 100 \mathrm{~g}$, respectively (Chuttong et al. 2016). Besides, Biluca et al. (2016) also showed a variation of moisture content, electric conductivity, acidity free, $\mathrm{pH}$ and diastase activity for stingless bee's honey samples produced by Melipona bicolor and Melipona quadriasciata which originated from Brazil.

The increasing production of stingless bees honey and overwhelming demands of the market for natural remedies necessitate research on the composition of honey from different geographical origins and species which reflected the originality of the honey products. Meanwhile, there is a lack of identity and quality standards on the stingless bees' products (Guerrini et al. 2009). The standards set by the Codex Alimentarius Commision (2001) could not be applied for the stingless bee honey as this standard is specifically applied to the Apis mellifera honey. Currently, the Standards (2017) is the main reference point for checking the physiochemical and nutritional properties of the stingless bee honey produced in Malaysia.

In the present study, the physicochemical and nutritional properties of Heterotrigona itama and Tetrigona binghami honey samples which originated from Sarawak, Malaysia were analysed and compared using a statistical approach. The honey samples were collected from the bee farms located at Nanga Dap (inland region) and Tanjung Manis (coastal region) of Sarawak, Malaysia (Table 1). Several analyses such as the moisture content, total phenolic content, predominant sugars content, 5-hydroxymethylfurfural (5-HMF), acetic acid, gluconic acid, $\mathrm{pH}$, ash, energy, protein, carbohydrates and energy were conducted. Following this, an independent T-test was employed using the SPSS software to determine the significant difference between the data for the honey samples.

\section{MATERIALS AND METHODS}

\section{HONEY SAMPLES}

The honey samples of raw stingless bee were provided by Rimbunan Hijau Bee Farms Sdn. Bhd, Sibu, Sarawak, Malaysia. As illustrated in Table 1, a total of ninety-six (96) Heterotrigona itama honey samples are collected from two bee farms in Sarawak. Meanwhile, ten (10) Tetrigona binghami honey samples are collected from both farms due to the limited availability of this resin dependant stingless bees. All the honey samples were harvested in November 2017.

The nectar sources was mainly from the Acacia mangium trees. The honey samples were extracted using laboratory syringe from independent honey hives and inserted into individual glass bottles. All the samples were refrigerated at $4^{\circ} \mathrm{C}$ until the analysis was conducted within a period of two weeks. 
TABLE 1. Sample collection

\begin{tabular}{lcc}
\hline Species & $\begin{array}{c}\text { Location of bee farm } \\
\text { (Sarawak, Malaysia) }\end{array}$ & $\begin{array}{c}\text { Number of honey } \\
\text { samples, } n\end{array}$ \\
\hline \multirow{2}{*}{ Heterotrigona itama } & Nanga Dap, Kanowit & 45 \\
& Tanjung Manis, Mukah & 51 \\
Tetrigona binghami & Nanga Dap, Kanowit & 5 \\
& Tanjung Manis, Mukah & 5 \\
\hline
\end{tabular}

\section{PHYSICOCHEMICAL ANALYSIS}

In the physicochemical analysis, six (6) types of chemical properties were investigated - moisture content, total phenolic content (TPC), sugars content, 5-Hydroxymethylfurfural (5-HMF), $\mathrm{pH}$ and organic acids.

\section{MOISTURE CONTENT}

The moisture content of the honey samples was measured using a refractometer (RHF-30ATC, China) according to AOAC Official Method 919.38 (AOAC 2016). All the measurements were performed at $20^{\circ} \mathrm{C}$.

\section{TOTAL PHENOLIC CONTENT (TPC)}

The TPC was examined using the Folin Ciocalteu spectrophotometric method (Kek et al. 2014). The honey sample $(1 \mathrm{~g})$ was diluted to $20 \mathrm{~mL}$ with distilled water. The honey solution $(1 \mathrm{~mL})$ was then pipetted into $5 \mathrm{~mL}$ of Folin Ciocalteu reagents $(0.2 \mathrm{~N})$ and incubated for $5 \mathrm{~min}$ in room temperature. Then, $4 \mathrm{~mL}$ of $7.5 \% \mathrm{w} / \mathrm{v}$ aqueous sodium carbonate solution was added and further incubated at room temperature for $2 \mathrm{~h}$. The absorbance of the mixture was measured at wavelength $765 \mathrm{~nm}$ against distilled water blank using the UV-VIS spectrophotometer (Cary 60, Agilent Technologies, U.S.A). Gallic acid was used to produce the standard calibration curve with the concentration ranging from 20 to $100 \mathrm{ppm}$. The total phenolic content was expressed in mg of gallic acid equivalent (GAE) per $\mathrm{kg}$ of honey.

\section{SUGARS CONTENT}

The predominant sugars content (fructose, glucose, maltose and sucrose) of the stingless bee honey were determined according to the AOAC Official Method 977.20 (AOAC 2016) using the high-performance liquid chromatography (HLPC) method. One gram of honey was dissolved in 20 $\mathrm{mL}$ of distilled water, filtered with $0.45 \mu \mathrm{m}$ filter paper followed by being injected into the HPLC 1200 Infinity LC system (Agilent Technologies, U.S.A) which was equipped with an autosampler and Evaporating Light Scattering Detector (ELSD). The analytical column used was Agilent Zorbax Carbohydrate $(150 \times 4.6 \mathrm{~mm}, 5 \mu)$ while the mobile phase was a mixture of acetonitrile and water (HPLC grade) in the ratio of 75:25 was used, at a flow rate $1.4 \mathrm{~mL} / \mathrm{min}$ with the oven temperature $30^{\circ} \mathrm{C}$. High purity sugar standards with known concentrations were used to produce standard calibration curves with concentration ranging from 2 to $10 \mathrm{~g} / \mathrm{L}$. The sugar content was expressed in $\mathrm{g}$ per $100 \mathrm{~g}$ of honey.

\section{5-HYDROXYMETHYLFURFURAL (5-HMF) ANALYSIS}

The 5-HMF analysis was conducted according to AOAC Official Method 980.23 (AOAC 2016) using the HPLC 1200 Infinity LC system (Agilent Technologies. U.S.A) equipped with an autosampler and a photodiode array detector. A $5 \% \mathrm{w} / \mathrm{v}$ of the honey solution was prepared and filtered through a $0.45 \mu \mathrm{m}$ nylon filter. Isocratic elution was performed on a ZORBAX Eclipse XDB C18 column size $4.6 \times 150 \mathrm{~mm}, 5 \mu \mathrm{m}$ (Agilent Technologies, U.S.A) and mobile phase methanol-water $(10: 90, \mathrm{v} / \mathrm{v})$ at a flow rate of $0.5 \mathrm{~mL} / \mathrm{min}$. The injection volume was $20 \mu \mathrm{L}$, column temperature of $25^{\circ} \mathrm{C}$ and a wavelength of 280 $\mathrm{nm}$ (Mendes et al. 1998). The standard calibration curve was generated with a concentration of 5-HMF from 5 to $25 \mathrm{mg} / \mathrm{kg}$. The amount of 5-HMF was recorded in the unit $\mathrm{mg}$ per $\mathrm{kg}$ of honey.

\section{pH ANALYSIS}

The $\mathrm{pH}$ of honey samples was determined according to the AOAC method 962.19 (AOAC 2016). A waterproof H160 $\mathrm{pH}$ meter (Hach, USA) was used to measure the $\mathrm{pH}$ value.

\section{ORGANIC ACIDS ANALYSIS}

The two organic acids, gluconic acid and acetic acid in the honey samples were identified and quantified using the HPLC method with minor modifications (Cherchi et al. 1994). One gram of the stingless bee honey sample was dissolved in $20 \mathrm{~mL}$ of distilled water, filtered with $0.45 \mu \mathrm{m}$ filter paper followed by being injected into the HPLC system equipped with a photodiode array detector. The identification of gluconic acid and acetic acid was performed by isocratic elution with reversed phase column, ZORBAX Eclipse XDB C18 (Agilent Technologies, U.S.A) and ion-exclusion column, Phenomenex Rezek ROA-Organic acid column (Phenomenex, U.S.A), respectively. The experiments were conducted with the mobile phase of $0.005 \mathrm{~N}$ sulphuric acid and flow rate of $0.5 \mathrm{~mL} / \mathrm{min}$. The injection volume was $10 \mu \mathrm{L}$ with the column temperature of $40^{\circ} \mathrm{C}$ and the $210 \mathrm{~nm}$ of wavelength. The organic acids standard curves were prepared for the concentrations ranging from 2 to $10 \mathrm{~g} / \mathrm{L}$ each. The organic acids were expressed in the form of percentage $(\%)$ of each compound. 


\section{PROXIMATE ANALYSIS}

In the proximate analysis, the energy value, carbohydrates content, crude protein and ash were evaluated. The analyses were performed according to AOAC (2016).

\section{ENERGY VALUE}

The energy value was calculated using (1).

Energy value (in kcal per $100 \mathrm{~g}$ honey)

$=[($ Protein $\times 4)+($ Total Carbohydrate $\times 4)+$ $($ Fat $\times 9)]$

\section{CARBOHYDRATES CONTENT}

The carbohydrates contents were calculated using (2).

Carbohydrates (in unit $\mathrm{g} / 100 \mathrm{~g}$ ) $=100-$

[Moisture + Ash + Fat + Protein]

\section{CRUDE PROTEIN}

The Kjeldahl method according to AOAC 920.52 (AOAC 2016) was applied in the determination ofa crude protein content. The honey sample ( $2 \mathrm{~g})$ was digested with digester machine (FOSS Labtec Line, Sweden) equipped with a scrubber at $420^{\circ} \mathrm{C}$ for $1 \mathrm{~h} 15 \mathrm{~min}$. After cooling, the digester tube underwent a distillation process with a distillation machine (FOSS Kjeltec 8100, Sweden). Then, titration step was done using $0.1 \mathrm{~N}$ of the hydrochloric acid $(\mathrm{HCl})$ with a receiver solution that consists of methyl red and bromocresol green as indicators in the $0.4 \%$ boric acid. The percentage of protein was calculated from the percentage of nitrogen content (3) with a universal conversion factor of 6.25 (4).

$$
\begin{aligned}
& \% \mathrm{~N}=\frac{[\text { (Normality of } \mathrm{HCl}) \times(\text { Volume sample }- \text { Volume blank }) \times 0.014 \times 100]}{\text { Weight of sample }} \\
& \% \text { Protein }=\% \mathrm{~N} \times 6.25
\end{aligned}
$$

\section{ASH CONTENT}

The ash content of the honey samples was measured according to the AOAC Official Method 920.181 (AOAC 2016) by placing a crucible at $100^{\circ} \mathrm{C}$ in an oven for $1 \mathrm{~h}$. After being cooled in a desiccator, the weight of the empty crucible was measured. Then, five grams of honey was placed into a crucible and then incinerated at $600^{\circ} \mathrm{C}$ for 2 $\mathrm{h}$ in the furnace (Nabertherm, Germany). The weight of the crucible was measured again after cooling in a desiccator.

\section{STATISTICAL DATA ANALYSIS}

Statistical analysis was carried out with IBM Statistical Package for Social Sciences (SPSS) (SPSS Inc, U.S.A) version 23. Independent T-test was conducted in order to evaluate the significant difference at a confidence level of $95 \%(p<0.05)$ between the quantified physicochemical and proximate compositions of the stingless bee honey samples from the two different geographical origins.

\section{RESULTS AND DISCUSSION}

The physicochemical analysis of the honey samples included moisture, total phenolic content, fructose content, glucose content, sucrose content, maltose content, 5-hydroxymethylfurfural (5-HMF), $\mathrm{pH}$ and organic acids (gluconic acid and acetic acid) (raw data not shown). Meanwhile, the protein, ash, energy and carbohydrates are the four proximate composition under investigation (raw data not shown). The present study conducted an independent T-test for the statistical analysis using the SPSS software version 23. Tables 2 and 3 show the statistical analysis results for physicochemical and proximate analysis for the honey samples. The results with a significant difference in the same column are denoted with different superscript letters in the same column.

From the ninety-six (96) Heterotrigona itama honey samples, the average moisture content is $30.80 \pm$ $1.37 \mathrm{~g} / 100 \mathrm{~g}$ while the moisture content of the ten (10) Tetrigona binghami honey samples is $36.45 \pm 1.75 \mathrm{~g} / 100$ $\mathrm{g}$, respectively (Table 2). Tetrigona binghami honey exhibits higher moisture content compared to the honey samples produced by the Heterotrigona itama species. An independent T-test shows a significant difference $(p<0.05)$ between the moisture content of both species. The stingless bee colonies are predominantly found in the tropical and subtropical regions of the world (Guerrini et al. 2009). Tropical areas which include rainforests have the benefit of abundant rainfall and high humidity. Hence, they contribute to the higher moisture content of stingless bee honey. In comparison with the normal stinging honey bee Apis mellifera, the stingless bee honey usually has a higher moisture content. For example, the moisture content of all the tested Saudi Apis mellifera honey was found to range from $12.12 \%$ to $17.32 \%$ (Alqarni et al. 2012).

The average value of the total phenolic content for Heterotrigona itama honey samples is $477.30 \pm 133.59 \mathrm{mg}$ $\mathrm{GAE} / \mathrm{kg}$ which is significantly lower compared to the total phenolic content of the Tetrigona binghami honey samples which is $578.00 \pm 137.50 \mathrm{mg} \mathrm{GAE} / \mathrm{kg}$ (Table 2). Honey from Trigona spp. exhibits higher levels of polyphenolic content compared to the honey from Apis spp (Kek et al. 2014). The existence of polyphenolic compounds in the honey is directly related to botanical resources and floral origins (Aljadi \& Kamaruddin 2004; Khalil et al. 2011).

Da Silva et al. (2013) reported there were fourteen (14) different phenolic compounds commonly present in the methanol extracts of the stingless honey samples. The polyphenolic compounds present in the honey are normally from the nectar of flowers, pollen and propolis (Da Silva et al. 2013; Estevinho et al. 2008). In addition, the total phenolic content may become a significant indicator of the antioxidant capacity of honey samples (Da Silva et al. 2013; Khalil et al. 2011). In the present study, the honey samples from the coastal area, Tanjung Manis have a higher total phenolic content $(509.20 \pm 126.7 \mathrm{mg} \mathrm{GAE} / \mathrm{kg})$ compared to honey from Nanga Dap $(435.38 \pm 133.9 \mathrm{mg}$ $\mathrm{GAE} / \mathrm{kg}$ ). Hence, the samples from Tanjung Manis might 


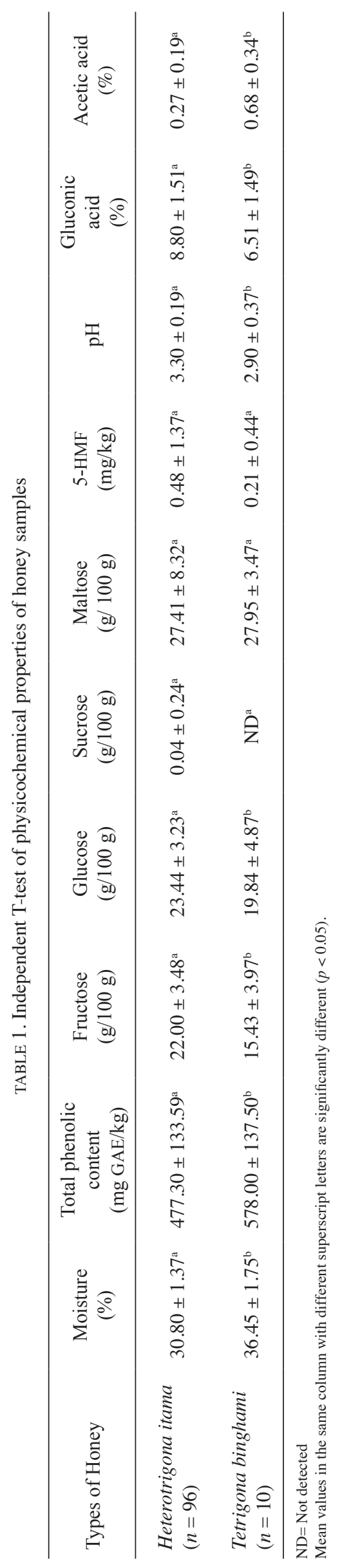


possess higher antioxidant capacity in comparison with the samples collected from the inland, Nanga Dap.

The total sugar content for Heterotrigona itama honey samples are higher compared to the Tetrigona binghami honey samples. According to Table 1, the average fructose content of Heterotrigona itama honey samples is $22.00 \pm$ $3.48 \mathrm{~g} / 100 \mathrm{~g}$ which is $42.6 \%$ higher compared to honey samples of Tetrigona binghami. Besides, an independent T-test indicates that there is a significant difference $(p<0.05)$ between the simple sugars found in the honey samples of Heterotrigona itama and Tetrigona binghami. The taste of raw honey produced by Heterotrigona itama is sweeter compared to the honey samples of Tetrigona binghami. However, the total simple sugars of these stingless bees' honey such as fructose and glucose are lower compared to the Tunisian honeys and Colombian stingless bee honey (Fuenmayor et al. 2013). The simple sugars such as fructose and glucose are reported to be lower in stingless bee honey samples compared to the Apis mellifera honey samples (Chuttong et al. 2016). Sucrose is not detected in most of the honey samples. A similar outcome is found by Chuttong et al. (2016) when only five out of the twenty-eight stingless bees honey samples were detected with sucrose.

The 5-HMF level is a major freshness indicator for honey. Fresh honey samples do not usually contain 5-HMF, but it increases depending on the $\mathrm{pH}$ of the honey and the storage condition (Alqarni et al. 2012). Standards (2017) permits a maximum 5-HMF level of $30.0 \mathrm{mg}$ per $\mathrm{kg}$ of honey. Meanwhile, the maximum proposed value of HMF by Codex (2001) is $80 \mathrm{mg} / \mathrm{kg}$. In the present study, eighty-one (81) out of ninety-six (96) honey samples of Heterotrigona itama do not contain 5-HMF. The total of $80 \%$ honey samples of Tetrigona binghami do not contain 5-HMF. The results indicated that these stingless bees honey samples are very fresh. Table 1 shows that there is no significant difference between the 5-HMF level of honey samples from both species.

Table 2 shows the $\mathrm{pH}$ of the honey samples of Heterotrigona itama ranges from 2.92 to 3.58. Meanwhile, the $\mathrm{pH}$ of the honey samples of Tetrigona binghami ranges from 2.01 to 3.46. An independent T-test shows that there is a significant difference $(p<0.05)$ of $\mathrm{pH}$ and organic acids between the honey samples of both species. The honey samples of Tetrigona binghami possess higher $\mathrm{pH}$ and acetic acid compared to the honey samples of Heterotrigona itama. On the other hand, stingless bee honey samples of Heterotrigona itama exhibit a higher percentage of gluconic acid. Gluconic acid or pentahydroxycaproic acid as it is also known is a product of glucose through a dehydrogenation reaction catalyzed by glucose oxidase. Fermentation is the most common conversion method to produce gluconic acid (Ramachandran et al. 2006). The presence of organic acids in stingless bee honey contributed to low $\mathrm{pH}$ and sourness of the honey.

Four types of proximate analyses were conducted in this study (Table 3). The honey samples were evaluated on the ash, protein, carbohydrates and energy. A significant differences $(p<0.05)$ can be found between the honey samples of Heterotrigona itama and Tetrigona binghami for all the proximate parameters.

The protein levels of honey samples of Tetrigona binghami was significantly higher $(0.26 \mathrm{~g} / 100 \mathrm{~g}$ to $1.49 \mathrm{~g} / 100 \mathrm{~g}$ ) compared to the honey samples of the Heterotrigona itama $(0.09 \mathrm{~g} / 100 \mathrm{~g}$ to $1.05 \mathrm{~g} / 100 \mathrm{~g})$. Kek et al. (2017) reported that the protein for Malaysian stingless bee honey was $0.85 \mathrm{~g} / 100 \mathrm{~g}$ which was similar to the findings of the current study. The protein level of the honey samples of Heterotrigona itama agrees well with Alvarez-Suarez et al. (2010) who stated that the honey normally possessed a small amount of protein. Consumption of protein and amino acids provides several benefits to humans which include immune-stimulating, anti-thrombotic and anti-inflammatory activities (Ares et al. 2013).

The carbohydrates level of the honey samples of Heterotrigona itama ranges from $64.75 \mathrm{~g} / 100 \mathrm{~g}$ to 72.04 $\mathrm{g} / 100 \mathrm{~g}$ is higher compared to the the carbohydrates content of the honey samples of Tetrigona binghami ranges from $59.88 \mathrm{~g} / 100 \mathrm{~g}$ to $65.06 \mathrm{~g} / 100 \mathrm{~g}$. The higher total amount of sugar in the honey samples of Heterotrigona itama has contributed to their high carbohydrate and energy levels. As illustrated in (1), the total energy value is dependent on the amount of protein and the carbohydrates. Therefore, the high level of protein and carbohydrates in the honey samples of Heterotrigona itama contributed to the high energy content of samples.

The mean value for the ash content of the honey samples of Heterotrigona itama $(0.29 \pm 0.16 \mathrm{~g} / 100 \mathrm{~g})$ and Tetrigona binghami $(0.20 \pm 0.04 \mathrm{~g} / 100 \mathrm{~g})$ is in permissible level set by the Standards (2017). The ash content in honey samples of Heterotrigona itama is significantly higher compared to the samples of Tetrigona binghami. The percentage of ash was measured according to the remaining inorganic residue found after the incineration of the honey samples.

TABLE 2. Independent T-test of proximate properties of honey samples

\begin{tabular}{lcccc}
\hline Types of Honey & $\begin{array}{c}\text { Protein } \\
(\mathrm{g} / 100 \mathrm{~g})\end{array}$ & $\begin{array}{c}\text { Ash } \\
(\mathrm{g} / 100 \mathrm{~g})\end{array}$ & $\begin{array}{c}\text { Energy } \\
(\mathrm{g} / 100 \mathrm{~g})\end{array}$ & $\begin{array}{c}\text { Carbohydrates } \\
(\mathrm{g} / 100 \mathrm{~g})\end{array}$ \\
\hline Heterotrigona itama $(n=96)$ & $0.39 \pm 0.19^{\mathrm{a}}$ & $0.29 \pm 0.16^{\mathrm{a}}$ & $275.31 \pm 5.92^{\mathrm{a}}$ & $68.53 \pm 1.39^{\mathrm{a}}$ \\
Tetrigona binghami $(n=10)$ & $0.99 \pm 0.38^{\mathrm{b}}$ & $0.20 \pm 0.04^{\mathrm{b}}$ & $256.43 \pm 11.61^{\mathrm{b}}$ & $62.37 \pm 1.89^{\mathrm{b}}$ \\
\hline
\end{tabular}

Mean values in the same column with different superscript letters are significantly different $(p<0.05)$ 
From the present study, a significant difference $(p<0.05)$ is observed for all the parameters except for sucrose, 5-HMF and maltose content. Given the proximate compositions, both types of honey samples are found with a significant difference $(p<0.05)$ in the ash, protein, carbohydrates and energy values.

\section{CONCLUSION}

The research findings suggested that the physicochemical properties of local Kelulut honey are in accordance with the Malaysia Standard, MS 2683: 2017: Kelulut (Stingless bee) honey - Specification (Standard 2017) and thus, we can conclude that honeys from both species are of high quality. However, the present study also indicated that the levels of protein and total phenolic content of honey of Tetrigona binghami species are significantly higher while the reducing sugar is relatively low compared to honey of Heterotrigona itama. According to Yeow et al. (2013), many factors influence the consumers' buying behaviours of honey and honey related products. The factors are product quality, medical conditions, brand reputation and pricing. Many of the purported beneficial health effects of consuming honey are due to its total phenolic contents. Since honey of T. binghami is rich in total phenolic contents, one might conclude that honey of this species is more valuable compared to the others. Nevertheless, the taste of honey is also an important consideration. Honey of $T$. binghami, with low reducing sugar, tastes sourer than honey of H. itama. Consumers that prefer sweetness in their honey may therefore go for the latter.

\section{ACKNOWLEDGEMENTS}

The authors would like to acknowledge University College of Technology Sarawak (UCTS/RESEARCH/2/2017/02; UCTS/RESEARCH/1/2019/07) for funding and for providing technical support, and Rimbunan Hijau Bee Farms Sdn. Bhd. for the supply of raw Kelulut honey.

\section{REFERENCES}

Aljadi, A.M. \& Kamaruddin, M.Y. 2004. Evaluation of the phenolic contents and antioxidant capacities of two Malaysian floral honeys. Food Chemistry 85(4): 513-518.

Alqarni, A.S., Owayss, A.A., Mahmoud, A.A. \& Hannan, M.A. 2012. Mineral content and physical properties of local and imported honeys in Saudi Arabia. Journal of Saudi Chemical Society 18(5): 618-625.

Alvarez-Suarez, J.M., Tulipani, S., Dıªz, D., Estevez, Y., Romandini, S., Giampieri, F., Damiani, E., Astolfi, P., Bompadre, S. \& Battino, M. 2010. Antioxidant and antimicrobial capacity of several monofloral Cuban honeys and their correlation with color, polyphenol content and other chemical compounds. Food and Chemical Toxicology 48: 2490-2499.

AOAC. 2016. Official Methods of Analysis of AOAC International. 20th ed.Association of Analytical Communities, Gaithersburg, MD, USA.
Ares, A.M., Nozal, M.J. \& Bernal, J. 2013. Extraction, chemical characterization and biological activity determination of broccoli health promoting compounds. Journal of Chromatography A 1313: 78-95.

Badolato, M., Carullo, G., Cione, E., Aiello, F. \& Caroleo, M.C. 2017. From the hive: Honey, a novel weapon against cancer. European Journal of Medicinal Chemistry 142: 290-299.

Biluca, F.C., Braghini, F., Gonzaga, L.V., Costa, A.C.O. \& Fett, R. 2016. Physicochemical profiles, minerals and bioactive compounds of stingless bee honey (Meliponinae). Journal of Food Composition and Analysis 50: 61-69.

Boussaid, A., Chouaibi, M., Rezig, L., Hellal, R., Donsì, Ferrari, G. \& Hamdi, S. 2018. Physicochemical and bioactive properties of six honey samples from various floral origins from Tunisia. Arabian Journal of Chemistry 11(2): 265-274.

Cherchi, A., Spanedda, L., Tuberoso, C. \& Cabras, P. 1994. Solid-phase extraction and high-performance liquid chromatographic determination of organic acids in honey. Journal of Chromatography A 669(1-2): 59-64.

Chuttong, B., Chanbang, Y., Sringarm, K. \& Burgett, M. 2016. Physicochemical profiles of stingless bee (Apidae: Meliponini) honey from South East Asia (Thailand). Food Chemistry 192: 149-155.

Codex, A. 2001. Revised Codex Standard for Honey. Codex Alimentarius.

Cortopassi-Laurino, M., Imperatriz-Fonseca, V.L., Roubik, D.W., Dollin, A., Heard, T., Aguilar, I., Venturieri, G.C., Eardley, C. \& Nogueira-Neto, P. 2006. Global meliponiculture: Challenges and opportunities. Apidologie 37(2): 275-292.

Da Silva, I.A.A., Da Silva, T.M.S., Camara, C.A., Queiroz, N., Magnani, M., de Novais, J.S. \& de Souza, A.G. 2013. Phenolic profile, antioxidant activity and palynological analysis of stingless bee honey from Amazonas, Northern Brazil. Food Chemistry 141(4): 3552-3558.

Escuredo, O., Dobre, I., Fernández-González, M. \& Seijo, M.C. 2014. Contribution of botanical origin and sugar composition of honeys on the crystallization phenomenon. Food Chemistry 149: 84-90.

Estevinho, L., Pereira, A.P., Moreira, L., Dias, L.G. \& Pereira, E. 2008. Antioxidant and antimicrobial effects of phenolic compounds extracts of Northeast Portugal honey. Food and Chemical Toxicology 46(12): 3774-3779.

Fuenmayor, C.A., Díaz-Moreno, A.C., Zuluaga-Domínguez, C.M. \& Quicazán, M.C. 2013. Honey of Colombian stingless bees: Nutritional characteristics and physicochemical quality indicators. In Pot Honey: A Legacy of Stingless Bees, edited by Vit, P., Pedro, S. \& Roubik, D. New York: Springer. pp. 383-394.

Guerrini, A., Bruni, R., Maietti, S., Poli, F., Rossi, D., Paganetto, G. \& Sacchetti, G. 2009. Ecuadorian stingless bee (Meliponinae) honey: A chemical and functional profile of an ancient health product. Food Chemistry 11(4): 1413-1420.

Gül, A. \& Pehlivan, T. 2018. Antioxidant activities of some monofloral honey types produced across Turkey. Saudi Journal of Biological Sciences 25(6): 1056-1065.

Jaapar, M.F., Halim, M., Mispan, M.R., Jajuli, R., Saranum, M.M., Zainuddin, M.Y., Ghazi, R. \& Ghani, I.A. 2016. The diversity and abundance of stingless bee (Hymenoptera: Meliponini) in Peninsular Malaysia. Advances in Environmental Biology 10(9): 1-9.

Kek, S.P., Chin, N.L., Tan, S.W., Yusof, Y.A. \& Chua, L.S. 2017. Classification of honey from its bee origin via chemical profiles and mineral content. Food Analytical Methods 10(1): 19-30. 
Kek, S.P., Chin, N.L., Yusof, Y.A., Tan, S.W. \& Chua, L.S. 2014. Total phenolic contents and colour intensity of Malaysian honeys from the Apis spp. and Trigona spp. bees. Agriculture and Agricultural Science Procedia 2: 150-155.

Khalil, M.I., Mahaneem, M., Jamalullail, S.M.S., Alam, N. \& Sulaiman, S.A. 2011. Evaluation of radical scavenging activity and colour intensity of nine Malaysian honeys of different origin. Journal of ApiProduct and ApiMedical Science 3(1): 4-11.

Kumar, A., Gill, J.P.S., Bedi, J.S., Manav, M., Ansari, M.J. \& Walia, G.S. 2018. Sensorial and physicochemical analysis of Indian honeys for assessment of quality and floral origins. Food Research International 108: 571-583.

Leonhardt, S.D., Schmitt, T. \& Blüthgen, N. 2011. Tree resin composition, collection behavior and selective filters shape chemical profiles of tropical bees (Apidae: Meliponini). PLoS ONE 6(8): e23445.

Mendes, E., Proenca, E.B., Ferreira, I.M.P.L.V.O. \& Ferreira, M.A. 1998. Quality evaluation of Portuguese honey. Carbohydrate Polymers 37(3): 219-223.

Michener, C.D. 2013. The meliponini. In Pot Honey: A Legacy of Stingless Bees, edited by Vit, P., Pedro, S. \& Roubik, D. New York: Springer. pp. 3-17.

Moniruzzaman, M., Chowdhury, M.A.Z., Rahman, M.A., Sulaiman, S.A. \& Gan, S.H. 2014. Determination of mineral, trace element, and pesticide levels in honey samples originating from different regions of Malaysia compared to Manuka honey. BioMed Research International 2014: 359890 .

Ramachandran, A., Snehalatha, C., Mary, S., Mukesh, B., Bhaskar, A.D. \& Vijay, V. 2006. The Indian Diabetes Prevention Programme shows that lifestyle modification and metformin prevent Type 2 diabetes in Asian Indian subjects with impaired glucose tolerance (IDPP-1). Diabetologia 49(2): 289-297.
Rasmussen, C. \& Cameron, S.A. 2009. Global stingless bee phylogeny supports ancient divergence, vicariance, and long distance dispersal. Biological Journal of the Linnean Society 99(1): 206-232.

Sousa, J.M., de Souza, E.L., Marques, G., Meireles, B., de Magalhães Cordeiro, Â.T., Gullón, B. \& Magnani, M. 2016. Polyphenolic profile and antioxidant and antibacterial activities of monofloral honeys produced by Meliponini in the Brazilian semiarid region. Food Research International 84: 61-68.

Standard, M. 2017. MS 2683: 2017. Kelulut (Stingless bee) honey-specification. Department of Standards Malaysia.

Tuksitha, L., Chen, Y.L.S., Chen, Y.L., Wong, K.Y. \& Peng, C.C. 2018. Antioxidant and antibacterial capacity of stingless bee honey from Borneo (Sarawak). Journal of Asia-Pacific Entomology 21(2): 563-570.

Yeow, S.H.C., Chin, S.T.S., Yeow, J.A. \& Tan, K.S. 2013 Consumer purchase intentions and honey related products. Journal of Marketing Research \& Case Studies c1-15. http:// dx.doi.org/10.5171/2013.197440.

School of Engineering and Technology

University College of Technology Sarawak

No. 1, Jalan Universiti

96000 Sibu, Sarawak Bumi Kenyalang

Malaysia

*Corresponding author; email: hiisl@ucts.edu.my

Received: 25 October 2018

Accepted: 23 May 2019 